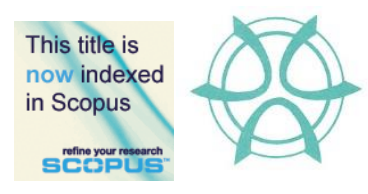

PLANNING MALAYSIA:

Journal of the Malaysian Institute of Planners

VOLUME 17 ISSUE 1 (2019), Page 328 - 337

\title{
RESIDENTIAL PROPERTY PRICE HIKE AND SPECULATION
}

\author{
Razali Haron $^{1}$ \& Khairunisah Ibrahim ${ }^{2}$ \\ ${ }^{1}$ Institute of Islamic Banking and Finance \\ ${ }^{2}$ Kulliyyah of Economics and Management Sciences \\ INTERNATIONAL ISLAMIC UNIVERSITY MALAYSIA
}

\begin{abstract}
This study analyzes the behaviour of property price in Malaysia by examining factors influencing the residential property prices. It aims to determine whether property prices hike in Malaysia can be explained by the fundamental factors or it is due to other unexplained factors, such as speculation. Findings from the study reveal that most of the factors did have significant influence on property price. In addition, the cointegration analysis indicates that the property price and its factors are cointegrated for all property market segments across states. This implies the presence of a long run relationship between the property price and its determining factors, despite slow adjustment of property price towards equilibrium in the long run. This study concludes that the residential property price hike in Malaysia is impacted by fundamental factors and is not speculative in nature.
\end{abstract}

Keywords: price hike, residential, property, speculation 
PLANNING MALAYSIA

Journal of the Malaysia Institute of Planners (2019)

\section{INTRODUCTION}

Empirical research documents that property price is closely related to a set of macroeconomic factors and market-specific conditions, which are expected to influence both the demand and the supply side of the property market (Ciarlone, 2015). Property prices in general are influenced by economic fundamentals as well as supply and demand dynamics of the local housing market. In general, property price has been showing an increasing pattern over time worldwide (Osmadi, Kamal, Hassan, \& Fattah, 2015; Kamal, Hassan, Osmadi, \& Fatah, 2015; Topalov, 2018).

Literature shows that researchers use the aggregate House Price Index (HPI) to represent property price. Glindro, Subhanij, Szeto and Zhud (2011) used the HPI in their studies on factors affecting property price in Asia-Pacific economies. Similarly, studies on Malaysia also used the HPI to represent property price (Lean \& Smyth, 2014; Ibrahim \& Law, 2014; Zandi, Supramaniam, Aslam, $\&$ Theng, 2015; Tang \& Tan, 2015). The HPI is made available by the National Property Information Centre (NAPIC). Apart from the aggregate HPI, NAPIC also publishes four sub-indices corresponding to various types of houses, namely, Terraced Houses, Semi-Detached Houses, Detached Houses and High-Rise Houses. Among the various types of houses, terraced houses seem to be the most important type of houses since it received the dominant weight in the construction of the aggregate HPI i.e. 72.7\% (Ibrahim \& Law, 2014). The phenomenon of property price hike has caught considerable attention from researchers and policy makers worldwide. Most studies focus on determining the factors contributing to the increasing pattern of the property price regardless of the economic landscapes. In doing so, researchers incorporate various possible factors based on different methods that may influence property price which include macroeconomic, demographic, industry, location and land/zoning (Ibrahim \& Law, 2014; Pillaiyan, 2015; Tang \& Tan, 2015; Kamal, Hassan, \& Osmadi, 2016; Topalov, 2018).

This study analyses the relationship between residential property price hike and speculation and is focusing specifically on the following objectives:

i. To determine the significant fundamental factors influencing the residential property price hike in Malaysia for the period of 2000-2015.

ii. To examine the long run behavior of the residential property price. This includes measuring the speed of adjustment towards the equilibrium, and

iii. To conclude on the presence of speculation in the residential property market in Malaysia.

\section{FACTORS AFFECTING PROPERTY PRICE}

Several commonly cited factors affecting property price have been highlighted in previous literature like the gross domestic products (GDP) (Ciarlone, 2015; 
Razali Haron \& Khairunisah Ibrahim

Residential Property Price Hike and Speculation

Pillaiyan, 2015), interest rates (Ramazan, Bradley, \& Bahadir, 2007; Tang \& Tan, 2015), inflation (Tsatsaronis \& Zhu, 2004), property loans growth (Ibrahim \& Law, 2014; Pillaiyan, 2015), money supply (Koivu, 2012; Pillaiyan, 2015), stock market performance (Lean \& Smyth, 2014), population growth (Jud \& Daniel, 2009; Ong, 2013) and cost of construction (Jud \& Daniel, 2009).

Following past literature, GDP is measured based on real GDP, interest rates based on average lending rates, inflation according to Consumer Price Index (CPI), property loans growth based on growth rate on housing loans, money supply based on M2, stock market performance according to the stock market index (KLCI), population growth based on growth in total population and cost of construction according to the producer price index (PPI).

\section{METHODOLOGY}

\section{Research Method}

To examine the relationship between property prices and the influencing factors, this study used the time-series econometric analysis including Dynamic Ordinary Least Square (DOLS), Johansen Cointegration Test, Autoregressive Distributed Lags Long Run Estimation (ARDL) and Vector Error Correction Model (VECM).

\section{Data Collection}

This study covers a period ranges from 2000 to 2015 . This study utilized quarterly data spanning from Q1 to Q4 of five house price indexes (HPI) for the national as well as the states level i.e. Aggregate HPI, Terraced HPI, Detached HPI, SemiDetached and High-Rise HPI. These data are sourced from NAPIC (www.napic.jpph.gov.my).

The data series were transformed into logarithm for consistency and standardization of measurement, obtaining linearity and reducing the problem of heteroscedasticity.

\section{DATA ANALYSIS AND FINDINGS}

Preliminary Analysis

Based on the data on the HPI, the average annual growth rates are computed to compare the rate between market segments and states in Malaysia. Table 1 shows the detail of the average annual growth in the HPI over the years (2000-2015).

Table 1: Average Annual Growth Rate per Quarter of HPI (2000-2015)

\begin{tabular}{lccccc}
\hline & Aggregate & Terrace & Detached & Semi-Detached & High-Rise \\
\hline National & 0.82 & 0.80 & 0.93 & 0.83 & 0.84 \\
Kuala Lumpur & 0.97 & 1.01 & 1.11 & 0.98 & 0.82
\end{tabular}




\begin{tabular}{llllll} 
Selangor & 0.81 & 0.83 & 0.82 & 0.85 & 0.61 \\
Johor & 0.56 & 0.54 & 0.71 & 0.68 & 0.67 \\
Penang & 0.92 & 1.01 & 0.64 & 0.64 & 1.01 \\
Perak & 0.84 & 0.81 & 1.04 & 0.88 & n.a. \\
Negeri Sembilan & 0.75 & 0.77 & 0.74 & 0.76 & 0.24 \\
Melaka & 0.24 & 0.26 & 0.15 & 0.21 & 0.11 \\
Kedah & 0.78 & 0.73 & 1.08 & 0.85 & n.a. \\
Pahang & 0.95 & 0.92 & 1.13 & 1.01 & n.a. \\
Terengganu & 0.98 & 0.91 & 1.14 & 1.04 & n.a. \\
Kelantan & 0.71 & 0.75 & 0.89 & 0.79 & n.a. \\
Perlis & 0.88 & 0.91 & n.a. & 0.95 & n.a. \\
Sabah & 1.12 & 1.11 & 1.38 & 1.16 & 1.03 \\
Sarawak & 0.85 & 0.79 & 1.01 & 0.87 & n.a. \\
\hline Sora
\end{tabular}

Note: n.a. $=$ data is not available

Source: Authors' calculation and secondary data analysis

Based on Table 1, the HPI (detached) recorded higher quarterly growth rate compared to other market segments. At the aggregate level, noticeable increases are recorded in Kuala Lumpur, Penang, Pahang, Terengganu and Sabah. These states also have recorded a higher quarterly average annual growth rates as compared to the national level.

\section{Dynamic Ordinary Least Square (DOLS) Regression}

This study employs DOLS regression to determine which factors are affecting property price in Malaysia, in line with the first objective of this study. The following discussion summarizes the result according to the property market segments.

\section{Aggregate segment}

GDP influenced residential property price only in Sabah. Interest rate influenced residential property price in all states except KL, Johor, Penang, Pahang, Terengganu and Sarawak. Loan growth does not influenced residential property price in any state. Money supply influenced residential property prices in all states except Johor and Kelantan. KLCI influenced residential property price only in KL. Population change influenced residential property price only in Perlis. Cost of construction influenced residential property price in all states except Terengganu and Sabah.

\section{Terraced segment}

GDP influenced residential property price only in Perlis. Interest rate influenced residential property price in all states except KL, Johor, Pahang and Sarawak. Loan growth influenced residential property price in Sabah and Sarawak. Money 
Razali Haron \& Khairunisah Ibrahim

Residential Property Price Hike and Speculation

supply influenced residential property prices in all states except Johor, Kedah, Kelantan and Perlis. KLCI influenced residential property price only in Sarawak. Population change influenced residential property price in Terengganu and Perlis. Cost of construction influenced residential property price in all states except Kedah, Terengganu, Kelantan and Sarawak.

\section{Detached segment}

GDP influenced residential property price in Penang, Perak, Kelantan and Sabah. Interest rate influenced residential property price in all states except KL, Penang, Melaka, Pahang, Terengganu and Sarawak. Loan growth influenced residential property price only in Johor. Money supply influenced residential property prices in Selangor, Johor, Penang, Perak and Sarawak. KLCI influenced residential property price in KL, Selangor, Kedah and Sabah. Population change influenced residential property price in Negeri Sembilan and Kelantan. Cost of construction influenced residential property price in all states except Melaka, Pahang, Terengganu, Kelantan, Perlis and Sarawak.

\section{Semi-Detached segment}

GDP influenced residential property price only in Sabah. Interest rate influenced residential property price in Melaka, Kedah, Pahang, Terengganu, Perlis and Sabah. Loan growth influenced residential property price in KL, Selangor, Johor and Kedah. Money supply influenced residential property prices in all states except KL, Johor, Pahang, Terengganu, Kelantan and Sabah. KLCI influenced residential property price in KL, Selangor and Penang. Population change influenced residential property price only in Kedah. Cost of construction influenced residential property price in all states except Penang, Pahang, Terengganu, Kelantan and Sabah.

\section{High Rise segment}

GDP influenced residential property price in Melaka and Sabah. Interest rate influenced residential property price in KL, Selangor, Negeri Sembilan, Melaka and Sabah. Loan growth influenced residential property price in Penang and Sabah. Money supply influenced residential property prices in KL and Penang. KLCI influenced residential property price only in Negeri Sembilan. Population change does not influenced property price in any state. Cost of construction influences residential property price in KL, Selangor, Johor, Penang, Negeri Sembilan, Melaka and Sabah.

In conclusion, this study found that the HPI are influenced by the identified factors. However inconsistencies are reported. For example, for detached segment, GDP is found to influence the property prices in Penang, Perak, Kelantan and Sabah but not in other states. Comparing between the factors, it is observed that the cost of construction and interest rates are the dominant 
factors influencing residential property prices (across states and market segments). The least influencing factors are loan growth and population change. In term of states, it is found that Kelantan, Terengganu and Pahang are the least influenced by the fundamental factors. Overall, the DOLS regression results indicate that the property price in Malaysia is explained by the fundamental factors.

\section{Johansen Cointegration Test}

This study proceeds with the co-integration test to examine the presence of cointegration between the property price and the identified factors. The presence of co-integration will indicate the existence of long run relationship between property price and the identified factors. A long run relationship will eventually establish equilibrium between property price and its factors.

Table 2: Johansen Co-integration Test

\begin{tabular}{lclccccc}
\hline Segment & National & KL & Selangor & Johor & Penang & Perak & N 9 \\
\hline Aggregate & 4 & 3 & 4 & 2 & 3 & 2 & 2 \\
Terraced & 4 & 3 & 4 & 2 & 3 & 3 & 2 \\
Detached & 2 & 2 & 2 & 2 & 2 & 2 & 2 \\
Semi-D & 4 & 3 & 3 & 2 & 3 & 4 & 2 \\
High-Rise & 3 & 3 & 3 & 3 & 2 & 1 & 3 \\
\hline
\end{tabular}

\begin{tabular}{lllllllll} 
Segment & Melaka & Kedah & Pahang & Terengganu & Kelantan & Perlis & Sabah & Sarawak \\
\hline Aggregate & 2 & 2 & 2 & 2 & 2 & 2 & 2 & 2 \\
Terraced & 2 & 2 & 3 & 3 & 2 & 2 & 3 & 2 \\
Detached & 2 & 3 & 3 & 2 & 2 & - & 3 & 2 \\
Semi-D & 2 & 2 & 2 & 2 & 3 & 3 & 3 & 2 \\
High-Rise & 3 & - & - & - & - & - & 4 & - \\
\hline
\end{tabular}

Notes: The above numbers represent the Trace test. The test indicates the number of co-integrating equations at the 0.05 level. Johansen Co-integration tests were based on the assumption of a constant and no trend in estimation equation.

Source: Authors' calculation and secondary data analysis

Based on Table 2, property prices and factors are co-integrated for all the property market segments, hence indicating the presence of long run relationship between property price and its determining factors. With the presence of cointegration between property price and factors, this study further analyzes the significance of the long run relationship in the following section.

\section{ARDL Long-Run Relationship}

This study employed the ARDL to determine the long run relationship between property price and its factors, in line with the second objective of this study. In conclusion, the study found that there exist a long run relationship between 
Razali Haron \& Khairunisah Ibrahim

Residential Property Price Hike and Speculation

residential property price and the influencing factors. However, inconsistencies are reported. For example, at the semi-detached segment, interest rates influenced the property prices in Kuala Lumpur, Selangor, Penang, Perlis and Sabah but not in other states. Comparing between factors, interest rates was the most dominant factor influencing residential property prices (across states and market segments). The least influencing factors were loan growth and population change. These results enhance our earlier finding based on the DOLS regression.

\section{Vector Error Correction Model (VECM)}

The presence of a long run relationship leads to the establishment of equilibrium whereby any deviation from equilibrium will eventually converge to equilibrium and stabilize. Following this, there is a need to examine the speed of adjustment (convergence) to equilibrium. As an example, in the long run, when the property price deviates from its equilibrium, it will converge at a certain speed of adjustment to its equilibrium. For this purpose, the VECM is suitable in measuring the speed of adjustment. The speed of adjustment is represented by the error correction term (ECT) in VECM.

Table 3: Error Correction Term (ECT) $(\lambda)$

\begin{tabular}{lcccccccc}
\hline Segment & National & KL & Selangor & Johor & Penang & Perak & N9 \\
\hline Aggregate & 0.0291 & 0.0938 & 0.0647 & 0.0021 & 0.0309 & -0.0832 & -0.0453 \\
Terraced & 0.0145 & 0.0679 & -0.0476 & 0.0101 & -0.0188 & -0.3403 & -0.0216 \\
Detached & -0.1420 & -0.2718 & -0.1499 & -0.0503 & 0.0883 & -0.0284 & -0.2807 \\
Semi-D & 0.0619 & -0.0431 & 0.0078 & 0.0331 & 0.0338 & -0.3387 & -0.2901 \\
High-Rise & 0.0399 & 0.0875 & 0.0317 & 0.0402 & 0.0380 & n.a. & -0.1789 \\
\hline \multicolumn{10}{c}{ Segment } & Melaka & Kedah & Pahang & Terengganu & Kelantan & Perlis & Sabah & Sarawak \\
\hline Aggregate & 0.0273 & -0.0519 & 0.0146 & -0.0146 & -0.0289 & 0.0281 & -0.0489 & 0.0440 \\
Terraced & 0.0298 & -0.1302 & 0.1013 & 0.0730 & 0.0605 & 0.0240 & -0.1897 & -0.0193 \\
Detached & -0.0026 & -0.3208 & -0.0621 & -0.1418 & -0.1018 & n.a. & 0.0575 & 0.0212 \\
Semi-D & -0.0488 & 0.0505 & -0.0170 & -0.0241 & -0.0397 & -0.1195 & -0.0588 & 0.0494 \\
High-Rise & -0.3059 & n.a. & n.a. & n.a. & n.a. & n.a. & 0.0006 & n.a. \\
\hline Nign
\end{tabular}

Notes: n.a. = data is not available

Source: Authors' calculation and secondary data analysis

Table 3 shows the significance of the ECT for all the property market segments. This indicates the presence of adjustment towards equilibrium. Comparatively, the detached segment has the highest rate of adjustment compared to other market segments. However, the magnitude of the adjustment was too slow. For example, for terraced, the speed was merely $1.45 \%$ (national). As a rule of thumb, the speed of adjustment $(\square)$ must be between $-2<\square<0$. This 
PLANNING MALAYSIA

Journal of the Malaysia Institute of Planners (2019)

finding supports the previous finding of Ibrahim and Law (2014) in which they recorded speed of adjustment of 10\% (Aggregate National) and 13\% (Terrace National) but no adjustment for other property market segments in their study on Malaysian property market.

Based on the ARDL and the VECM, this study concludes that despite the existence of the long run relationship between property price and its factors, convergence to equilibrium is too slow. This indicates a persistent deviation of property price from its equilibrium. This finding therefore supports Tang and Tan (2015) conclusion on the inefficiency of property market price in Malaysia.

\section{CONCLUSION}

The increasing trend of property price in Malaysia has raised the attention of many parties, be it from home buyers, investors, researchers, policy makers and economists. Factors influencing property price have been widely discussed and numerous factors have been examined by past researchers in the attempt to better understand the property market price behavior. Some common factors in the literature display consistent results whereas others are specific to particular economies and market segments. Accordingly, this study examines the factors influencing property price in Malaysia.

The findings from this study show that based on the different segments of property prices (aggregate, terraced, detached, semi-detached, high-rise) at the different states, most of the factors do have significant influence on residential property price hike. By examining the national and states level data, this study differs from the previous studies such as Pillaiyan (2015) that concludes the presence of speculation in the Malaysian property market. Pillaiyan (2015) concludedthat the property price has deviated from the economic fundamentals for the last 15 years due to insignificant influence of GDP on property price based only on the national data (aggregate). Having analyzed the national and states level data, this study hence provides rigorous information on the behavior of property price in Malaysia.

This study expands the analysis and looks into the dynamic nature of the property price by examining the long run behaviour of the price and its association with the identified factors. The co-integration analysis indicates that the property price and its factors are co-integrated for all property market segments across states, hence implying the presence of a long run relationship between the property price and its determining factors. By using the ARDL to determine the long run relationship between property price and the factors, this study found that most of the factors significantly influence property price in the long run.

This study however recorded a slow adjustment of property price towards equilibrium in the long run. This implies a persistent deviation from price equilibrium reflecting inefficiency in the residential property market in Malaysia. 
Razali Haron \& Khairunisah Ibrahim

Residential Property Price Hike and Speculation

The inefficiency could be attributed to the slow response in supply of housing units in responding to demand due to among others, land scarcity and preference of developers in building specific residential projects.

In conclusion, with the significant influence of factors affecting residential property prices and the presence of long run integration, this study concludes that the residential property price hike in Malaysia is supported by fundamental factors and is not speculative in nature.

\section{ACKNOWLEDGEMENT}

This research is funded by NAPREC R\&D Grant Scheme No. 22/16.

\section{REFERENCES}

Ciarlone, A.A. (2015). Property cycles in emerging economies. Studies in Economics and Finance, 32(1), 17 - 52.

Glindro, E.T., Subhanij, T., Szeto, J., \& Zhud, H. (2011). Determinants of property price in nine Asia-Pacific economies. International Journal of Central Banking, 7(3), 163-204.

Ibrahim, M.H., \& Law, S.H. (2014). Property price and bank credits in Malaysia: An aggregate and disaggregate analysis. Habitat International, 42, 111-120.

Jud, G.D., \& Daniel, T.W. (2009). The dynamics of metropolitan housing prices. Journal of Real Estate Research, 23(1), 29-45.

Kamal, E. M., Hassan, H., Osmadi, A., \& Fatah, H.A. (2015). Housing price control: is it a way forward? Sustainable Development, 2, 1225-1235.

Kamal, E. M., Hassan, H., \& Osmadi, A. (2016). Factors influencing the housing price: developers' perspective. International Journal of Social, Behavioral, Educational, Economic, Business and Industrial Engineering, 10(5), 1603-1609.

Koivu, T. (2012). Monetary policy, asset prices and consumption in China. Economic Systems, 36, 307-325.

Lean, H.H., \& Smyth, R. (2014). Dynamic interaction between property price and stock prices in Malaysia. International Journal of Strategic Property Management, 18(2), 163-177.National Property Information Centre (NAPIC). (2015). The Malaysian House Price Index by House Type. Retrieved from http://napic.jpph.gov.my/portalOng, T.S. (2013). Factors affecting the price of housing in Malaysia. Journal of Emerging Issues in Economics, Finance and Banking (JEIEFB), 1(5), 414-429.

Osmadi, A., Kamal, E.M., Hassan, H. \& Fattah, H.A. (2015). Exploring the elements of housing price in Malaysia. Asian Social Science, 11(24), 26-38.

Pillaiyan, S. (2015). Macroeconomic drivers of property price in Malaysia. Canadian Social Science, 11(9), 119-130.

Ramazan, S., Bradley, T. E., \& Bahadir, A. (2007). Macroeconomic variables and the housing market in Turkey. Emerging Markets Finance and Trade, 43(5), 5-19.

Tang, T.C., \& Tan, P.P. (2015). Real interest rate and property price in Malaysia: an empirical study. Economics Bulletin, 35(1), 270-275. 
PLANNING MALAYSIA

Journal of the Malaysia Institute of Planners (2019)

Topalov, C. (2018). Prices, profits and rents in residential development: France 1960-80. In B. Michael, E. Michael, B. Vincenzo \& F. Marino (Eds.), Land rent, housing and urban planning: A European perspective (1-21). London : Routledge.

Tsatsaronis, K., \& Zhu, H. (2004). What drives housing price dynamics: cross-country evidence. BIS Quarterly Review, March, 65-78.

Zandi, G., Supramaniam, M., Aslam, A., \& Theng, L.K. (2015). The economic factors affecting residential property price: the case of Penang Island. International Journal of Economics and Finance, 7(12), 200-210.

Received: $28^{\text {th }}$ October 2018. Accepted: $1^{\text {st }}$ March 2019 